\title{
Pengaruh Ukuran Perusahaan dan Pengungkapan CSR Terhadap Nilai Perusahaan dengan GCG Sebagai Variabel Pemoderasi
}

\author{
Diah Surya Nita Dwi Lestari ${ }^{1}$ \\ Ni Gusti Putu Wirawati ${ }^{2}$
}

${ }^{1}$ Fakultas Ekonomi dan Bisnis Universitas Udayana (Unud), Bali, Indonesia
email: nitasuryalestari@ gmail.com/Telp: 081339889740
${ }^{2}$ Fakultas Ekonomi dan Bisnis Universitas Udayana (Unud), Bali, Indonesia

\begin{abstract}
ABSTRAK
Nilai perusahaan dapat mencerminkan bagaimana keadaan perusahaan dari segi finansial dan nonfinansial. Perusahaan perlu memperhatikan faktor-faktor yang dapat mempengaruhi naik turunnya nilai perusahaan. Penelitian ini bertujuan untuk mengetahui pengaruh ukuran perusahaan dan pengungkapan Corporate Social Responsibility (CSR) terhadap nilai perusahaan dengan Good Corporate Governance (GCG) sebagai variabel pemoderasi. Penelitian ini dilakukan pada perusahaan go public yang terdaftar di Bursa Efek Indonesia dan mengikuti program Corporate Governance Perception Index berturut-turut dari tahun 2011-2015. Jumlah populasi dalam penelitian ini adalah 539 perusahaan dan sampel yang diambil sebanyak 6 perusahaan, dengan metode probability sampling. Pengumpulan data dilakukan dengan teknik observasi non partisipan. Teknik analisis yang digunakan adalah regresi linier berganda dan Moderated Regression Analysis. Hasil analisis menunjukkan bahwa ukuran perusahaan berpengaruh positif pada nilai perusahaan, pengungkapan Corporate Social Responsibility (CSR) berpengaruh positif pada nilai perusahaan, GCG memperkuat hubungan ukuran perusahaan dan pengungkapan CSR terhadap nilai perusahaan.
\end{abstract}

Kata kunci: Nilai perusahaan, ukuran perusahaan, CSR, GCG

\begin{abstract}
This study aims to determine the effect of firm size and disclosure of Corporate Social Responsibility (CSR) to corporate value with Good Corporate Governance (GCG) as moderating variable. This research was conducted at a public listed company listed on the Indonesia Stock Exchange and followed the Corporate Governance Perception Index program successively from 2011-2015. The number of population in this research is 539 companies and samples taken as many as 6 companies, with probability sampling method. Data collection was done by non participant observation technique. Analytical techniques used are multiple linear regression and Moderated Regression Analysis. The results of the analysis show that firm size has a positive effect on corporate value, Corporate Social Responsibility (CSR) disclosure has a positive effect on company value, GCG strengthens the firm size and disclosure of Corporate Social Responsibility (CSR) to company value.

Keywords: company value, company size, CSR, GCG
\end{abstract}

\section{PENDAHULUAN}

Ukuran perusahaan merupakan salah satu faktor keuangan yang dianggap mampu mempengaruhi nilai perusahaan. Ukuran perusahaan menjadi gambaran kemampuan finansial perusahaan dalam suatu periode tertentu. Ukuran perusahaan mencerminkan aset yang dimiliki suatu perusahaan. Pada umumnya 
Diah Surya Nita Dwi Lestari dan Ni Gusti Putu Wirawati. Pengaruh...

perusahaan besar memiliki nilai aset yang lebih tinggi dibandingkan perusahaan kecil, sehingga perusahaan besar lebih mudah memasuki pasar modal (Hardian dan Asyik, 2016). Ukuran perusahaan yang besar menunjukkan perusahaan mengalami perkembangan sehingga investor akan menilai positif dan nilai perusahaan akan meningkat (Puspita, 2011).

Tujuan jangka pendek perusahaan adalah untuk memperoleh laba secara maksimal, sedangkan tujuan jangka panjangnya adalah untuk meningkatkan nilai perusahaan (Kusumayanti dan Astika, 2016). Tingginya nilai perusahaan akan membuat investor yakin terhadap keberlangsungan perusahaan dan juga prospeknya di masa mendatang. Terdapat beberapa faktor yang dapat mempengaruhi nilai perusahaan, yaitu faktor keuangan dan non keuangan. Faktor keuangan yang dimaksud, yaitu seperti profitabilitas, leverage, ukuran perusahaan, likuiditas, struktur modal, kebijakan deviden, dan solvabilitas. Faktor non keuangan contohnya pengungkapan Corporate Social Responsibility (CSR) dan penerapan Good Corporate Governance (GCG).

Program CSR yang dilakukan secara integratif, dapat berkontribusi menjaga kelangsungan bisnis. Hal ini menyatakan bahwa penerapan CSR oleh suatu perusahaan sangat penting dan dapat membantu keberlangsungan perusahaan yang sekaligus dapat menaikkan derajat nilai perusahaan. Hukum dan regulasi mewajibkan perusahaan untuk melakukan analisis mengenai dampak lingkungan (AMDAL) tertuang dalam Undang-Undang No. 40 Pasal 74 Tahun 2007 menyatakan bahwa perusahaan yang kegiatan usahanya berhubungan dengan sumber daya alam wajib melakukan tanggung jawab sosial dan 
lingkungan. Peraturan lain, yaitu Undang-Undang No. 25 Tahun 2007 tentang Penanaman Modal pasal 15 (b) yang menyatakan bahwa setiap penanam modal memiliki kewajiban untuk melaksanakan tanggung jawab sosial perusahaan untuk mengungkapkan informasi mengenai tata kelola perusahaan dimana di dalamnya juga termasuk uraian mengenai aktivitas dan biaya yang dikeluarkan berkaitan dengan tanggung jawab sosial perusahaan terhadap masyarakat dan lingkungan pada laporan tahunan perusahaan. Adanya regulasi yang mengatur tentang CSR tersebut dapat menyadarkan perusahaan untuk mulai menyadari pentingnya penerapan CSR dan melakukan pengungkapan CSR.

Selain faktor keuangan, faktor non keuangan juga dapat mempengaruhi kinerja dan nilai perusahaan. CSR merupakan wujud pertanggungjawaban yang dilaksanakan oleh perusahaan. Deegan (2004) menyatakan bahwa CSR dilandasi oleh prinsip triple bottom lines, dimana perusahaan tidak hanya memberikan informasi mengenai pelaksanaan kegiatan ekonominya saja, tetapi juga kegiatan sosial lingkungannya. Hal ini dapat menciptakan hubungan timbal balik antara perusahaan dengan masyarakat dan lingkungan sekitar secara sinergis. Pentingnya pengungkapan CSR pada perusahaan perbankan diteliti oleh Branco dan Rodrigues (2006) yaitu tentang pengungkapan CSR di beberapa perusahaan di Portugis, dimana CSR merupakan hal yang penting bagi perusahaan perbankan karena dapat membantu komunikasi dengan para stakeholders. Hal ini selaras dengan penelitian McDonald dan Rudle-Thiele (2008) yang menyatakan bahwa kegiatan CSR yang dilakukan oleh perusahaan perbankan di dunia memiliki tujuan untuk memperkuat citra perusahaan dan hubungan dengan para 
Diah Surya Nita Dwi Lestari dan Ni Gusti Putu Wirawati. Pengaruh...

stakeholders. Kaur (2015) berpendapat bahwa pelaksanaan CSR oleh perusahaan merupakan sinyal positif bagi para investor, yang tentu akan menghasilkan keuntungan finansial bagi perusahaan. Karena investor cenderung tertarik dengan perusahaan yang memiliki image atau citra positif di mata masyarakat luas agar dapat memastikan keberlangsungan perusahaan tersebut.

Penelitian yang menggunakan nilai perusahaan telah banyak dilakukan, diantaranya oleh Hardian dan Asyik (2016) dalam penelitiannya menyatakan bahwa ukuran perusahaan tidak memiliki pengaruh signifikan terhadap nilai perusahaan, tetapi Pratama dan Wiksuana (2016) menyatakan bahwa ukuran perusahaan berpengaruh positif terhadap nilai perusahaan. Hasil penelitian Kusumayanti dan Astika (2016) menyatakan bahwa CSR berpengaruh secara negatif terhadap nilai perusahaan. Ratnadewi dan Ulupui (2016) dalam penelitiannya menyatakan bahwa pengungkapan CSR memiliki pengaruh positif terhadap nilai perusahaan dan GCG berpengaruh negatif dan signifikan terhadap hubungan antara pengungkapan CSR dengan nilai perusahaan. Sejalan dengan hasil penelitian Astiyani dan Astika (2014) yang menyatakan bahwa pengungkapan CSR berpengaruh positif pada nilai perusahaan, namun dalam penelitian ini dikatakan bahwa GCG mampu memoderasi pengaruh pengungkapan CSR pada nilai perusahaan.

Inkonsistensi atas hasil penelitian sebelumnya menjadi dasar dan motivasi untuk memasukan GCG sebagai variabel pemoderasi pengaruh ukuran perusahaan dan pengungkapan CSR pada nilai perusahaan. Penelitian sebelumnya lebih banyak menekankan mengenai pengaruh CSR dan GCG terhadap nilai 
perusahaan. Perbedaan penelitian ini dengan penelitian sebelumnya, yaitu dengan menambahkan variabel ukuran perusahaan sebagai variabel independen dan GCG sebagai variabel yang memoderasi ukuran perusahaan terhadap nilai perusahaan. Penelitian ini melakukan pengkajian ulang terkait apakah ukuran perusahaan dan pengungkapan CSR berpengaruh terhadap nilai perusahaan. Selain itu penelitian ini meneliti mengenai apakah GCG mampu memoderasi pengaruh ukuran perusahaan terhadap nilai perusahaan dan pengaruh pengungkapan CSR terhadap nilai perusahaan. Corporate Governance (CG) merupakan tata kelola perusahaan. Sedangkan GCG merupakan tata kelola perusahaan yang baik. GCG digunakan untuk meningkatkan keberhasilan usaha dan akuntabilitas perusahaan guna mewujudkan nilai perusahaan yang baik. Perusahaan yang menerapkan GCG dalam jangka panjang dapat menjamin keberlangsungan usaha dan peningkatan profit secara signifikan. Penerapan GCG diduga dapat mengoptimalkan nilai perusahaan bagi pemegang saham dengan tetap memperhatikan pemangku kepentingan lainnya. Penerapan GCG yang dapat mempengaruhi nilai perusahaan diduga bahwa variabel ini dapat memperkuat pengaruh ukuran perusahaan dan pengungkapan CSR terhadap nilai perusahaan.

Adapun rumusan masalah dalam penelitian ini adalah 1) Apakah ukuran perusahaan berpengaruh pada nilai perusahaan? 2) Apakah pengungkapan CSR berpengaruh pada nilai perusahaan? 3) Apakah GCG mampu memoderasi pengaruh ukuran perusahaan pada nilai perusahaan? 4) Apakah GCG mampu memoderasi pengaruh pengungkapan CSR pada nilai perusahaan? 
Diah Surya Nita Dwi Lestari dan Ni Gusti Putu Wirawati. Pengaruh...

Bringham dan Hauston (2013) menyatakan bahwa isyarat atau signal adalah suatu tindakan yang diambil perusahaan untuk memberi petunjuk bagi investor tentang bagaimana manajemen memandang prospek perusahaan. Signalling Theory menyatakan bahwa perusahaan yang berkualitas baik dengan sengaja akan memberikan sinyal pada pasar, dengan demikian pasar diharapkan dapat membedakan perusahaan yang berkualitas baik dan buruk (Suwisnaya, 2017). Sinyal biasanya berupa informasi yang mengandung unsur penting bagi investor dan pelaku bisnis. Umumnya informasi tersebut akan memberikan gambaran mengenai keadaan perusahaan, dan catatan masa lalu maupun keadaan yang akan datang yang berdampak bagi kelangsungan hidup perusahaan. Perusahaan melakukan pengungkapan CSR dengan harapan dapat meningkatkan reputasi dan nilai perusahaan (Rustiarini, 2010). Jenis dan bentuk sinyal yang dikeluarkan oleh perusahaan, pada dasarnya bertujuan agar pihak eksternal dapat melakukan perubahan penilaian atas perusahaan atau dengan kata lain perusahaan harus mengeluarkan sinyal yang memiliki kekuatan informasi yang mampu mengubah penilaian pihak eksternal perusahaan (Gumanti, 2009:4).

Definisi stakeholder menurut Freeman dan McVea (2001) adalah setiap kelompok atau individu yang dapat mempengaruhi atau dipengaruhi oleh pencapaian tujuan organisasi. Teori stakeholder adalah teori yang menggambarkan kepada pihak mana saja perusahaan bertanggungjawab. Teori stakeholder berpendapat bahwa perusahaan bukanlah entitas yang hanya beroperasi untuk kepentingannya sendiri namun memberikan manfaat bagi stakeholders. Tujuan utama dari perusahaan adalah menyeimbangkan konflik 
antara stakeholders. Perusahaan dituntut untuk menjaga hubungan dengan para stakeholders dengan cara mengakomodir kebutuhan para stakeholders terutama yang berhubungan dengan operasional perusahaan. Freeman dan McVea (2001) menyatakan bahwa pendekatan stakeholder dilatarbelakangi adanya keinginan untuk membangun suatu kerangka kerja yang responsive terhadap masalah yang dihadapi para manajer saat itu yaitu perubahan lingkungan.

Pengertian teori legitimasi dikemukakan oleh O’Donovan (2002) yaitu : "Legitimacy theory as the idea that in order for an organization to continue operating successfully, it must act in a manner that society deems socially acceptable”. Dari penjelasan diatas, teori legitimasi mengandung arti bahwa organisasi/perusahaan secara berkesinambungan harus memastikan apakah mereka telah beroperasi di dalam norma-norma yang dijunjung masyarakat dan memastikan bahwa aktivitas mereka bisa diterima pihak luar. Teori legitimasi menjelaskan bahwa suatu perusahaan melakukan kegiatan usaha dengan batasan, norma, nilai sosial dan memberikan reaksi atas batasan-batasan tersebut dengan mendorong pentingnya perilaku organisasi yang memerhatikan lingkungan. Teori legitimasi menganjurkan perusahaan untuk dapat meyakinkan masyarakat bahwa kinerja dan operasionalnya tidak merugikan dan dapat diterima di masyarakat. Pengungkapan CSR dalam annual report perusahaan merupakan salah satu cara untuk meningkatkan citra perusahaan yang baik sehingga dapat memberikan daya tarik bagi calon investor untuk menanamkan modalnya dan membantu investor dalam pengambilan keputusan investasi (Setiawan, 2014). 
Diah Surya Nita Dwi Lestari dan Ni Gusti Putu Wirawati. Pengaruh...

Tujuan utama perusahaan menurut theory of the firm adalah untuk memaksimumkan kekayaan atau nilai perusahaan (Salvatore, 2005). Semakin tinggi nilai perusahaan, semakin besar kemakmuran yang akan diterima oleh pemilik perusahaan. Memaksimumkan nilai perusahaan identik dengan memaksimumkan profit dalam pengertian ekonomi. Maksimalisasi kemakmuran pemegang saham tidak mengingkari adanya social objectives dan kewajiban sosial. Kepekaan terhadap faktor eksternal juga merupakan syarat penting untuk mempertahankan keberlangsungan suatu perusahaan. Perusahaan harus dapat memaksimumkan kemakmuran pemegang saham dalam kendala legal dan sosial dan bertanggung jawab terhadap perubahan lingkungan (Wiagustini, 2010:10). Keberhasilan dalam memaksimalkan nilai perusahaan akan memberikan dampak kepada lingkungan sosial secara merata.

Ukuran perusahaan menggambarkan besar kecilnya suatu perusahaan. Semakin besar ukuran suatu perusahaan menunjukkan bahwa perusahaan tersebut mengalami perkembangan. Hal tersebut akan meningkatkan nilai perusahaan dan kelak direspon positif oleh para investor. Perusahaan yang besar akan cenderung memiliki kondisi yang lebih stabil, sehingga investor akan tertarik untuk membeli saham perusahaan tersebut, yang berdampak pada peningkatan harga saham perusahaan tersebut di pasar modal (Analisa, 2011).

Perusahaan dengan ukuran lebih besar memiliki akses lebih besar dan luas untuk mendapat sumber pendanaan dari luar, sehingga untuk memperoleh pinjaman akan menjadi lebih mudah karena dikatakan bahwa perusahaan dengan ukuran besar memiliki kesempatan lebih besar untuk memenangkan persaingan 
atau bertahan dalam industry (Sugiono dan Jogi, 2013). Perusahaan yang sudah well-established akan lebih mudah memperoleh modal di pasar modal. Karena kemudahan akses tersebut berarti perusahaan besar memiliki fleksibilitas yang lebih besar pula.

Perkembangan CSR di Indonesia dapat dilihat dari dua perspektif yang berbeda. Pertama, pelaksanaan CSR memang merupakan praktik bisnis secara sukarela (discretionary business practice) artinya pelaksanaan CSR lebih banyak merupakan suatu inisiatif dari perusahaan dan bukan merupakan suatu kewajiban yang harus dilakukan oleh perusahaan ataupun dituntut oleh regulasi perundangundangan. Kedua, pelaksanaan CSR bukan lagi merupakan praktik bisnis sukarela, melainkan pelaksanaannya sudah diatur oleh undang-undang (bersifat mandatory).

Tanggung jawab sosial perusahaan atau CSR merupakan salah satu dari beberapa tanggung jawab perusahaan kepada para pemangku kepentingan. Menurut Freeman dan McVea (2001), tanggung jawab sosial perusahaan adalah menjalankan bisnis sesuai dengan keinginan pemilik perusahaan (owners), biasanya dalam bentuk menghasilkan uang sebanyak mungkin dengan senantiasa mengindahkan aturan dasar yang digariskan dalam suatu masyarakat sebagaimana diatur oleh hukum dan perundang-undangan. CSR merupakan komitmen Perseroan untuk berperan serta dalam pembangunan ekonomi berkelanjutan guna meningkatkan kualitas kehidupan dan lingkungan yang bermanfaat, baik bagi Perseroan sendiri, komunitas setempat, maupun masyarakat pada umumnya (UU PT No.40 Tahun 2007 pasal 1 ayat 3). 
Diah Surya Nita Dwi Lestari dan Ni Gusti Putu Wirawati. Pengaruh...

CG dalam pelaksanaan dan pengendaliannya akan melibatkan organ-organ di dalam perusahaan yang akan berperan sebagai pelaksana dan pengawas. Pengelolaan perusahaan tersebut harus diawasi untuk menjamin terjadinya optimalisasi nilai perusahaan. Form for Corporate in Indonesia (FCGI) mendefinisikan CG sebagai serangkaian mekanisme yang mengarahkan dan mengendalikan suatu perusahaan agar operasional perusahaan berjalan sesuai dengan harapan para pemangku kepentingan. FCGI juga mendefinisikan GCG sebagai struktur, sistem, dan proses yang digunakan oleh organ-organ perusahaan sebagai upaya untuk memberikan nilai tambah perusahaan secara berkesinambungan dalam jangka panjang, dengan tetap memperhatikan kepentingan stakeholder lainnya, berdasarkan peraturan yang berlaku dan untuk menciptakan nilai tambah bagi pihak-pihak yang berkepentingan, perusahaan perlu melaksanakan tata kelola perusahaan yang baik atau GCG.

Ukuran perusahaan umumnya mencerminkan aset yang dimiliki oleh perusahaan tersebut. Dimana perusahaan dengan ukuran besar pada umumnya memiliki aset yang lebih besar daripada perusahaan dengan ukuran kecil. Ukuran perusahaan juga menunjukkan perkembangan perusahaan tersebut. Perusahaan yang besar biasanya memiliki citra positif di mata investor karena kestabilan berkelanjutan dapat diprediksikan terjadi pada perusahaan tersebut. Penelitian yang dilakukan oleh Gill dan Obradovich (2012) menyatakan bahwa ukuran perusahaan berpengaruh positif pada nilai perusahaan. Besar kecilnya ukuran perusahaan dapat menjadi indikasi bahwa perusahaan mempunyai komitmen yang tinggi untuk terus memperbaiki kinerjanya. Hal ini selaras dengan hasil penelitian 
Pratama (2015) dan Okada (2006) yang juga membuktikan bahwa ukuran perusahaan berpengaruh positif pada nilai perusahaan.

Perusahaan yang telah mengungkapkan informasi pertanggungjawaban sosial umumnya memiliki image di masyarakat, dan khususnya di kalangan pebisnis, karena selain memperhatikan kepentingan stakeholder dan shareholder juga memperhatikan lingkungan sekitar, implikasinya perusahaan akan mendapatkan respon dari masyarakat akan eksistensinya di dunia bisnis dan keberlanjutan perusahaan yang nantinya akan meningkatkan nilai perusahaan. Teori stakeholder menyatakan bahwa perusahaan merupakan entitas yang tidak hanya beroperasi untuk kepentingan sendiri namun juga memberikan manfaat bagi para stakeholders, sementara dalam teori legitimacy dikatakan bahwa perusahaan harus dapat meyakinkan masyarakat bahwa kinerja dan operasionalnya tidak merugikan sekitar dan dapat diterima di masyarakat. Dengan demikian perusahaan menyadari pentingnya kelangsungan hidup perusahaan juga bergantung pada hubungan perusahaan dengan lingkungan dan masyarakat sekitar (Umbara dan Suryanawa, 2014). Penelitian yang dilakukan oleh Putri (2017) menunjukkan bahwa pengungkapan CSR berpengaruh positif pada nilai perusahaan. Hal ini selaras dengan penelitian yang dilakukan oleh Astiyani dan Astika (2014), Medyawati (2014) dan Servaes and Tamayo (2012) yang menunjukkan bahwa pelaksanaan aktivitas CSR yang baik dapat meningkatkan nilai perusahaan

Ukuran perusahaan menggambarkan besar kecilnya suatu perusahaan. Semakin besar ukuran suatu perusahaan menunjukkan bahwa perusahaan tersebut 
Diah Surya Nita Dwi Lestari dan Ni Gusti Putu Wirawati. Pengaruh...

mengalami perkembangan. Tata kelola perusahaan atau CG dipandang perlu untuk menciptakan nilai tambah oleh suatu perusahaan. Perusahaan yang berkembang dan menerapkan GCG akan meningkatkan nilai perusahaan dan direspon positif oleh investor. Hal ini menunjukkan bahwa GCG dapat menciptakan nilai tambah yang berdampak pada perusahaan dan dapat meningkatkan nilai perusahaannya.

Hasil penelitian Kusumayanti dan Astika (2016) serta Pratama dan Wiksuana (2016) menyatakan bahwa ukuran perusahaan berpengaruh pada nilai perusahaan, sedangkan hasil penelitian Retno dan Denies (2012) menunjukkan bahwa GCG berpengaruh pada nilai perusahaan. Menurut Rustiari (2010) beberapa hal yang dapat menyebabkan GCG berpengaruh pada nilai perusahaan yaitu : 1) Tingginya kesadaran perusahaan menerapkan GCG sebagai suatu kebutuhan, bukan sekedar kepatuhan terhadap regulasi yang ada. 2) Manajemen perusahaan tertarik manfaat jangka panjang penerapan GCG. 3) Meningkatnya kepemilikan saham oleh manajemen dan investor institusi menyebabkan tekanan kepada perusahaan untuk menerapkan GCG pun semakin besar. 4) Keberadaan dewan komisaris dan komite audit dalam perusahaan dapat memantau perusahaan dalam melaksanakan GCG. 5) Unsur budaya yang berkembang di lingkungan usaha nasional sangat menunjang perkembangan penerapan GCG.

Implementasi program CSR oleh perusahaan yang berorientasi dari dalam ke luar harus terlebih dahulu membenahi kepatuhan perusahaan terhadap hukum. Perusahaan harus menjalankan bisnisnya dengan baik dan perlu mengembangkan sejumlah kebijakan untuk menuntun pelaksanaan CSR. Implementasi CSR juga 
menjadi salah satu prinsip pelaksanaan GCG, sebagaimana dijelaskan dalam Pedoman Umum GCG Indonesia khususnya prinsip responsibilitas dinyatakan bahwa perusahaan harus taat kepada peraturan perundang-undangan serta melakukan tanggung jawab terhadap masyarakat dan lingkungan sehingga dapat terpelihara kesinambungan usaha jangka panjang. Ketika perusahaan menerapkan GCG diharapkan kinerjanya akan meningkat menjadi lebih baik sehingga dapat meningkatkan aktivitas CSR yang dilakukan perusahaan yang berdampak pada nilai perusahaan. Astiyani dan Astika (2014) menunjukkan bahwa CG mampu memoderasi pengaruh pengungkapan CSR pada nilai perusahaan. Hal ini menunjukkan bahwa CG dapat mendorong kesadaran masyarakat terhadap lingkungan berdasarkan pedoman umum GCG. Nahda dan Harjito (2011) juga menunjukkan bahwa GCG sebagai variabel moderasi dapat mempengaruhi hubungan antara CSR dan nilai perusahaan

Berdasarkan tinjauan pustaka dan beberapa penelitian terdahulu maka dapat dirumuskan hipotesis sebagai berikut:

$\mathrm{H}_{1}$ :Ukuran perusahaan berpengaruh positif pada nilai perusahaan $\mathrm{H}_{2}$ : Pengungkapan CSR berpengaruh positif pada nilai perusahaan $\mathrm{H}_{3}$ : GCG memperkuat pengaruh ukuran perusahaan pada nilai perusahaan $\mathrm{H}_{4}$ : GCG memperkuat pengaruh pengungkapan CSR pada nilai perusahaan.

\section{METODE PENELITIAN}

Variabel-variabel yang digunakan dalam penelitian ini yaitu : 1) Menurut Indriantoro dan Supomo (2016:63) variabel dependen adalah tipe variabel yang dijelaskan atau dipengaruhi oleh variabel independen. Variabel dependen adalah variabel yang diduga sebagai akibat (presumed effect variable). Variabel dependen dalam penelitian ini adalah nilai perusahaan (Y). 2) Menurut 
Diah Surya Nita Dwi Lestari dan Ni Gusti Putu Wirawati. Pengaruh...

Indriantoro dan Supomo (2016:63) variabel independen adalah tipe variabel yang menjelaskan atau mempengaruhi variabel lain. Variabel independen dinamakan pula dengan variabel yang diduga sebagai sebab (presumed cause variabel) dari variabel dependen. Variabel independen dalam penelitian ini adalah ukuran perusahaan $\left(\mathrm{X}_{1}\right)$ dan pengungkapan $\operatorname{CSR}\left(\mathrm{X}_{2}\right)$. 3) Variabel moderasi adalah variabel yang dapat memperkuat atau memperlemah hubungan antara variabel independen dengan variabel dependen. Variabel moderasi dalam penelitian ini adalah $\mathrm{GCG}\left(\mathrm{X}_{3}\right)$.

Populasi dalam penelitian ini adalah perusahaan go public yang terdaftar di BEI dari tahun 2011 - 2015. Sampel pada penelitian akan dipilih sedemikian rupa sehingga dapat mewakili sifat-sifat populasi (Sugiyono, 2014). Teknik penentuan sampel dalam penelitian ini ditentukan dengan metode non probability sampling, yaitu teknik purposive sampling berdasarkan pertimbangan. Elemen populasi yang dipilih sebagai sampel dibatasi pada elemen-elemen yang dapat memberikan informasi berdasarkan pertimbangan tertentu (Indriantoro dan Supomo, 2016:115). Adapun kriteria dalam pengambilan sampel dalam penelitian ini adalah 1) Perusahaan yang terdaftar di BEI dan mengikuti program CGPI tahun 2011-2015. 2) Perusahaan yang menyajikan laporan keuangan dan laporan tahunan secara lengkap.

Jenis data yang digunakan dalam penelitian ini adalah data kuantitatif. Data kuantitatif yaitu data dalam bentuk angka, dapat dinyatakan dan dapat diukur dengan satuan hitung (Sugiyono, 2014:17). Data tersebut diadakan dari laporan 
keuangan perusahaan go public yang terdaftar di Bursa Efek Indonesia tahun 2011-2015 yang memenuhi kriteria sampel penelitian.

Sumber data yang digunakan dalam penelitian ini adalah data sekunder. Data sekunder adalah sumber tidak langsung atau memberikan data secara tidak langsung, seperti melalui orang lain atau dokumen (Sugiyono, 2014:129). Data sekunder dalam penelitian ini diperoleh dari laporan keuangan perusahaan go public yang memenuhi kriteria sampel penelitian yang terdaftar di Bursa Efek Indonesia tahun 2011-2015 yang dapat diakses melalui www.idx.co.id.

Metode pengumpulan data yang digunakan dalam penelitian ini adalah metode observasi nonpartisipan, yaitu teknik pengumpulan data dengan observasi dimana peneliti tidak terlibat langsung dan hanya sebagai pengamat independen (Sugiyono, 2013:204). Data dikumpulkan dengan cara mengamati, mencatat, serta mempelajari buku-buku, karya ilmiah berupa skripsi, jurnal akuntansi, dan situs internet resmi mengenai nilai perusahaan, ukuran perusahaan, pengungkapan CSR dan GCG.

Analisis linier berganda adalah pengujian yang dilakukan untuk mengetahui ada tidaknya pengaruh atas dua atau lebih variabel independen terhadap variabel dependen. Analisis linier berganda adalah pengujian yang dilakukan untuk mengetahui ada tidaknya pengaruh ukuran perusahaan $\left(\mathrm{X}_{1}\right)$ dan pengungkapan CSR $\left(\mathrm{X}_{2}\right)$ terhadap nilai perusahaan $(\mathrm{Y})$. Persamaan regresi linier berganda adalah sebagai berikut :

$$
\mathrm{Y}=\alpha+\beta_{1} \mathrm{X}_{1}+\beta_{2} \mathrm{X}_{2}+\mathrm{e}
$$


Keterangan :

$\mathrm{Y}=$ Nilai Perusahaan

$\alpha=$ Konstanta

$\beta_{1-} \beta_{2}=$ Koefisien regresi

$\mathrm{X}_{1}=$ Ukuran Perusahaan

$\mathrm{X}_{2}=$ Pengungkapan CSR

$\mathrm{e}=$ error

Moderated Regression Analysis (MRA) bertujuan untuk mengetahui pengaruh variabel moderating atas variabel independen dan variabel dependen apakah memperkuat atau memperlemah. Persamaan Moderated Regression Analysis adalah sebagai berikut:

$$
\mathrm{Y}=\alpha+\beta_{1} \mathrm{X}_{1}+\beta_{2} \mathrm{X}_{2}+\beta_{3} \mathrm{X}_{1} \mathrm{X}_{3}+\beta_{4} \mathrm{X}_{2} \mathrm{X}_{3}+\mathrm{e}
$$

Keterangan :

$\mathrm{Y}=$ Nilai Perusahaan

$\alpha=$ Konstanta

$\beta_{1-} \beta_{4}=$ Koefisien regresi

$\mathrm{X}_{1}=$ Ukuran Perusahaan

$\mathrm{X}_{2}=$ Pengungkapan CSR

$\mathrm{X}_{3}=$ Good Corporate Governance

$\mathrm{X}_{1} \mathrm{X}_{3}=$ interaksi antara Ukuran Perusahaan dengan Good Corporate Governance $\mathrm{X}_{2} \mathrm{X}_{3}=$ interaksi antara Pengungkapan CSR dengan Good Corporate Governance $\mathrm{e}=$ error

\section{HASIL DAN PEMBAHASAN}

Sampel awal yang diperoleh berjumlah 8 perusahaan, namun setelah diseleksi berdasarkan kriteria yang telah ditetapkan maka diperoleh sampel akhir sebanyak 6 perusahaan. Penentuan sampel menggunakan metode purposive sampling dengan kriteria yang telah ditentukan. Penentuan sampel dapat dilihat pada tabel 1. berikut ini. 
Tabel 1.

Hasil Penentuan Sampel

\begin{tabular}{lc}
\hline \multicolumn{1}{c}{ Kriteria } & Jumlah \\
\hline Perusahaan go public yang terdaftar di BEI tahun 2011-2015 & 539 \\
Perusahaan go public yang terdaftar di BEI dan tidak mengikuti & $(531)$ \\
program CGPI tahun 2011-2015 & $(2)$ \\
Perusahaan yang tidak menyajikan laporan keuangan dan laporan & \\
tahunan secara lengkap & 6 \\
Sampel & 30 \\
\hline
\end{tabular}

Sumber: Data diolah, 2017

Berdasarkan hasil uji statistik deskriptif diperoleh sebanyak 30 data observasi yang berasal dari jumlah perusahaan yang terdaftar di Bursa Efek Indonesia (BEI) dan konsisten mengikuti program CGPI tahun 2011-2015. Sampel yang berjumlah 30 memiliki data yang lengkap untuk kepentingan penelitian. Hasil statistik deskriptif disajikan pada Tabel 2.

Tabel 2.

Hasil Statistik Deskriptif

\begin{tabular}{lccccc}
\hline \multicolumn{1}{c}{ Variabel } & N & Min & Max & Mean & $\begin{array}{c}\text { Std. } \\
\text { Deviation }\end{array}$ \\
\hline UP & 30 & 20,91 & 26,36 & 23,97 & 1,040 \\
CSR & 30 & 0,177 & 0,708 & 0,436 & 0,181 \\
GCG & 30 & 83,65 & 93,29 & 87,52 & 2.616 \\
Nilai Perusahaan & 30 & 0,18 & 3,18 & 1,455 & 0,908 \\
Valid N (listwise) & & & & & \\
\hline
\end{tabular}

Sumber: Data diolah, 2017

Berdasarkan Tabel 2. dapat dilihat bahwa variabel nilai perusahaan yang diproksikan dengan Tobins'q menunjukkan nilai minimum sebesar 0,18 dan nilai maksimum sebesar 3,18. Mean sebesar 1,455 dan standar deviasi sebesar 0,908. Nilai rata-rata sebesar 1,455 menunjukkan bahwa rata-rata nilai perusahaan yang menjadi sampel penelitian dikategorikan sebagai perusahaan yang tumbuh dan berkembang. Standar deviasi pada variabel nilai perusahaan menunjukkan bahwa standar penyimpangan data terhadap nilai rata-ratanya adalah 0,908 . 
Diah Surya Nita Dwi Lestari dan Ni Gusti Putu Wirawati. Pengaruh...

Variabel ukuran perusahaan yang diproksikan dengan Size menunjukkan nilai minimum sebesar 20,91, nilai maksimum sebesar 26,36, mean sebesar 23,97 dan standar deviasi sebesar 1,040. Nilai rata-rata sebesar 23,97 menunjukkan bahwa ukuran perusahaan yang menjadi sampel penelitian tergolong tinggi. Standar deviasi pada variabel ukuran perusahaan menunjukkan bahwa standar penyimpangan data terhadap nilai rata-ratanya adalah 1,040 .

Variabel pengungkapan CSR yang diproksikan dengan Indeks CSRI yang dihitung dengan melihat jumlah item pengungkapan CSR yang dilakukan perusahaan menunjukkan nilai minimum sebesar 0,177 , nilai maksimum sebesar 0,708, mean sebesar 0,436, dan standar deviasi sebesar 0,181. Nilai rata-rata sebesar 0,436 menunjukkan bahwa pengungkapan CSRI pada perusahaan yang menjadi sampel penelitian tergolong rendah. Standar deviasi pada variabel pengungkapan CSR menunjukkan bahwa standar penyimpangan data terhadap nilai rata-ratanya adalah 0,181 .

Variabel GCG yang didapat dari ranking level IICG yang dikeluarkan oleh CGPI, menunjukkan nilai minimum sebesar 83,65, nilai maksimum sebesar 93,29, mean sebesar 87,25 dan standar deviasi sebesar 2,616. Nilai rata-rata sebesar 87,25 menunjukkan bahwa perusahaan yang menjadi sampel penelitian dikategorikan sebagai perusahaan sangat terpercaya.

Variabel nilai perusahaan, ukuran perusahaan, pengungkapan CSR dan GCG memiliki nilai rata-rata lebih besar daripada standar deviasinya. Hal ini menunjukkan bahwa kualitas data dari variabel tersebut baik, karena nilai rata-rata 
yang lebih besar dari nilai standar deviasinya mengidentifikasikan bahwa standar error dari variabel tersebut kecil (Ghozali, 2016).

Sebelum dianalisis dengan teknik regresi, maka model persamaan regresi harus melalui uji asumsi klasik, meliputi: uji normalitas, uji multikolinearitas, uji heteroskedastisitas, dan uji autokorelasi yang secara rinci dijelaskan dalam Tabel 3. sebagai berikut:

Tabel 3.

Hasil Uji Asumsi Klasik

\begin{tabular}{lll}
\hline Uji Asumsi Klasik & Hasil Uji & Keterangan \\
\hline Uji Normalitas & $\mathrm{p}(0,442) ;(0,359) ;(0,375) ;$ & Berdistribusi normal \\
& $(0,058)>0,05$ & \\
Uji Autokorelasi & $1,765<1,922$ & Bebas dari autokorelasi \\
Uji Multikolinearitas & Tolerance $(0,795) ;(0,595) ;$ & \\
& $(0,656)>0,1$ & \\
& VIF $(1,259) ;(1,682) ;(1,523)<$ & Tidak ada multikolinearitas \\
& 10 & \\
Uji Heteroskedastisitas & $\mathrm{p}(0,653) ;(0,540) ;(0,663)>$ & Tidak terjadi \\
& 0,05 & heteroskedastisitas \\
\hline
\end{tabular}

Sumber: Data diolah, 2017

Analisis linier berganda adalah pengujian yang dilakukan untuk mengetahui ada tidaknya pengaruh ukuran perusahaan $\left(\mathrm{X}_{1}\right)$ dan pengungkapan CSR $\left(\mathrm{X}_{2}\right)$ terhadap nilai perusahaan $(\mathrm{Y})$ yang disajikan dalam Tabel 4. sebagai berikut:

Tabel 4.

Hasil Analisis Regresi Linier Berganda

\begin{tabular}{|c|c|c|c|c|c|}
\hline \multirow[t]{2}{*}{ Variabel } & \multicolumn{2}{|c|}{$\begin{array}{l}\text { Unstandardized } \\
\text { Coefficients }\end{array}$} & \multirow{2}{*}{$\begin{array}{c}\text { Standardized } \\
\text { Coefficients } \\
\text { Beta } \\
\end{array}$} & \multirow[t]{2}{*}{$\mathbf{T}$} & \multirow[t]{2}{*}{ Sig. } \\
\hline & B & Std. Error & & & \\
\hline (Constant) & 16,433 & 2,647 & & 6,208 & 0,000 \\
\hline UP & 0,683 & 0,119 & 0,782 & 5,758 & 0,000 \\
\hline CSR & 1,646 & 0,681 & 0,329 & 2,418 & 0,023 \\
\hline Adjusted $\mathbf{R}^{2}$ & & & & & 0,521 \\
\hline F Hitung & & & & & 16,751 \\
\hline Sig. F & & & & & $0,000^{\mathrm{a}}$ \\
\hline
\end{tabular}

Berdasarkan hasil yang diperoleh pada koefisien hasil regresi pada Tabel

4. diatas adalah sebagai berikut: 
Diah Surya Nita Dwi Lestari dan Ni Gusti Putu Wirawati. Pengaruh...

$$
\mathrm{Y}=7,624+0,683 \mathrm{X}_{1}+1,646 \mathrm{X}_{2}+\mathrm{e}
$$

Berdasarkan hasil perhitungan uji $\mathrm{F}$ pada Tabel 4. yaitu hasil analisis regresi linier berganda menunjukkan nilai dari uji F sebesar 0,000. Signifikansi sebesar 0,000 yang lebih kecil daripada 0,05 memiliki arti bahwa model regresi layak untuk digunakan. Berdasarkan hasil perhitungan uji $\mathrm{F}$ pada Tabel 4. yaitu hasil analisis regresi linier berganda menunjukkan nilai dari uji $\mathrm{F}$ sebesar 0,000 . Signifikansi sebesar 0,000 yang lebih kecil daripada 0,05 memiliki arti bahwa model regresi layak untuk digunakan.

Berdasarkan hasil regresi linier berganda yang disajikan pada Tabel 4. diperoleh nilai signifikansi uji t untuk variabel ukuran perusahaan sebesar 0,000 lebih kecil dari $\alpha=0,05$ dan nilai koefisien regresi sebesar 0,683 yang berarti ukuran perusahaan berpengaruh positif pada nilai perusahaan, sehingga hipotesis pertama dalam penelitian ini diterima. Hasil penelitian ini mendukung hasil penelitian yang dilakukan oleh Pratama dan Wiksuana (2016) serta Kusumayanti dan Astika (2016) yang membuktikan bahwa ukuran perusahaan berpengaruh positif terhadap nilai perusahaan.

Berdasarkan hasil regresi linier berganda yang disajikan pada Tabel 4.6 diperoleh nilai signifikansi uji t untuk variabel pengungkapan CSR sebesar 0,023 lebih kecil dari $\alpha=0,05$ dan nilai koefisien regresi sebesar 1,646 yang berarti pengungkapan CSR berpengaruh positif pada nilai perusahaan, sehingga hipotesis kedua dalam penelitian ini diterima. Hasil penelitian ini mendukung hasil penelitian yang dilakukan oleh Umbara dan Suryanawa (2014) serta Ratnadewi 
dan Ulupui (2016) yang membuktikan bahwa pengungkapan CSR berpengaruh positif pada nilai perusahaan.

Moderated Regression Analysis (MRA) bertujuan untuk mengetahui pengaruh variabel moderating atas variabel independen dan variabel dependen apakah memperkuat atau memperlemah. Hasil uji MRA disajikan dalam Tabel 5. berikut ini:

Tabel 5. Hasil Analisis Regresi dengan Moderasi

\begin{tabular}{|c|c|c|c|c|c|}
\hline \multirow[t]{2}{*}{ Variabel } & \multicolumn{2}{|c|}{$\begin{array}{l}\text { Unstandardized } \\
\text { Coefficients }\end{array}$} & \multirow{2}{*}{$\begin{array}{c}\text { Standardized } \\
\text { Coefficients } \\
\text { Beta } \\
\end{array}$} & \multirow[t]{2}{*}{$\mathbf{T}$} & \multirow[t]{2}{*}{ Sig. } \\
\hline & B & Std. Error & & & \\
\hline (Constant) & 7,624 & 5,759 & & 1,324 & 0,198 \\
\hline UP & 1,511 & 0,390 & 1,731 & 3,874 & 0,001 \\
\hline CSR & 1,036 & 0,864 & 0,207 & 1,200 & 0,042 \\
\hline GCG & 0,710 & 0,555 & 2,044 & 1,278 & 0,013 \\
\hline $\mathrm{UP} * \mathrm{GCG}$ & 0,922 & 0,386 & 2,756 & 2,386 & 0,025 \\
\hline $\mathrm{CSR} * \mathrm{GCG}$ & 0,128 & 0,389 & 0,372 & 0,328 & 0,045 \\
\hline Adjusted $\mathrm{R}^{2}$ & & & & & 0,613 \\
\hline F Hitung & & & & & 10,172 \\
\hline Sig. F & & & & & $0,000^{\mathrm{a}}$ \\
\hline
\end{tabular}

Sumber: Data diolah, 2017

Berdasarkan hasil yang diperoleh pada koefisien hasil regresi pada Tabel diatas adalah sebagai berikut :

$$
\mathrm{Y}=7,624+1,511 \mathrm{X}_{1}+1,036 \mathrm{X}_{2}+0,922 \mathrm{X}_{1} \mathrm{X}_{3}+0,128 \mathrm{X}_{2} \mathrm{X}_{3}+\mathrm{e}
$$

Berdasarkan hasil perhitungan uji F pada Tabel 4. yaitu hasil analisis MRA menunjukkan nilai dari uji F sebesar 0,000. Signifikansi sebesar 0,000 lebih kecil daripada 0,05 memiliki arti bahwa model regresi layak untuk digunakan. Berdasarkan hasil uji koefisien determinasi pada Tabel 5. menunjukkan bahwa nilai adjusted $R$ square model sebesar 0,613 artinya sebesar 61,3 persen naik turunnya nilai perusahaan dipengaruhi oleh ukuran perusahaan, pengungkapan 
Diah Surya Nita Dwi Lestari dan Ni Gusti Putu Wirawati. Pengaruh...

CSR dan GCG sementara sisanya sebesar 38,7 persen dijelaskan oleh variabel lain diluar model regresi yang digunakan.

Berdasarkan hasil uji koefisien determinasi pada Tabel 5. menunjukkan bahwa nilai adjusted $R$ square model sebesar 0,613 artinya sebesar 61,3 persen naik turunnya nilai perusahaan dipengaruhi oleh ukuran perusahaan, pengungkapan CSR dan GCG sementara sisanya sebesar 38,7 persen dijelaskan oleh variabel lain diluar model regresi yang digunakan.

Berdasarkan hasil MRA yang disajikan pada Tabel 5. diperoleh nilai signifikansi uji t untuk variabel pemoderasi GCG memperkuat pengaruh ukuran perusahaan terhadap nilai perusahaan sebesar 0,025 lebih kecil dari $\alpha=0,05$ dan nilai koefisien regresi sebesar 0,922 yang berarti GCG mampu memperkuat pengaruh ukuran perusahaan pada nilai perusahaan, sehingga hipotesis ketiga dalam penelitian ini diterima. . Hal ini dapat menunjukkan bahwa semakin tinggi penerapan GCG maka semakin tinggi kegiatan operasionalnya dan ukuran perusahaan semakin besar. Ukuran perusahaan yang besar akan mencerminkan bahwa perusahaan tersebut sedang mengalami perkembangan dan pertumbuhan yang baik sehingga dapat meningkatkan nilai perusahaan.

Berdasarkan hasil MRA yang disajikan pada Tabel 5. diperoleh nilai signifikansi uji $\mathrm{t}$ untuk variabel pemoderasi GCG memperkuat pengaruh pengungkapan CSR terhadap nilai perusahaan sebesar 0,045 lebih kecil dari $\alpha=$ 0,05 dan nilai koefisien regresi sebesar 0,128 yang berarti GCG mampu memperkuat pengaruh pengungkapan CSR pada nilai perusahaan, sehingga hipotesis keempat dalam penelitian ini diterima. Hasil penelitian ini konsisten 
dengan hasil penelitian yang dilakukan oleh Astiyani dan Astika (2014) serta Harjito dan Nahda (2011) yang membuktikan bahwa GCG mampu memperkuat pengaruh pengungkapan CSR terhadap nilai perusahaan.

Hasil penelitian ini memberikan tambahan informasi mengenai bagaimana ukuran perusahaan dan pengungkapan CSR mempengaruhi nilai perusahaan dengan GCG sebagai variabel pemoderasi. Terdapat bukti empiris yang diperoleh melalui penelitian ini yang menunjukkan bahwa ukuran perusahaan dan pengungkapan CSR berpengaruh positif terhadap nilai perusahaan dan GCG memperkuat pengaruh ukuran perusahaan dan pengungkapan CSR terhadap nilai perusahaan. Hal ini menunjukkan semakin besar ukuran perusahaan dan semakin tinggi pengungkapan CSR serta didukung dengan penerapan GCG pada suatu perusahaan maka akan semakin meningkat nilai perusahaan tersebut.

Hal ini didukung dengan teori sinyal yang menyebutkan bahwa perusahaan yang berkualitas baik akan sengaja memberikan sinyal kepada pasar, dan memberikan informasi mengenai keadaan perusahaan yang berdampak bagi kelangsungan hidup perusahaan, karena ukuran perusahaan yang besar dan tingginya pelaksanaan CSR merupakan suatu sinyal positif bagi para investor yang kemudian akan menghasilkan keuntungan finansial bagi perusahaan karena investor cenderung tertarik dengan perusahaan yang memiliki citra positif di kalangan masyarakat luas agar dapat memastikan keberlangsungan perusahaan tersebut. Informasi yang dikeluarkan perusahaan tentunya akan dapat mengubah pemikiran pihak eksternal untuk menambah bahan pertimbangan dalam berinvestasi. 
Diah Surya Nita Dwi Lestari dan Ni Gusti Putu Wirawati. Pengaruh...

Hasil penelitian ini dapat menjadi referensi, masukan, tambahan dan bahan pertimbangan bagi calon investor dalam memilih perusahaan untuk melakukan investasi, serta bagi perusahaan-perusahaan hasil penelitian ini dapat menjadi feedback atas pengungkapan yang dilakukan dan hendaknya agar tetap mempertahankan dan meningkatkan pengungkapan CSR dan penerapan GCG untuk dapat memaksimumkan nilai perusahaan.

\section{SIMPULAN}

Berdasarkan hasil analisis data dan pembahasan yang telah diuraikan diatas, maka dapat ditarik kesimpulan bahwa ukuran perusahaan berpengaruh positif pada nilai perusahaan. Hal ini berarti semakin tinggi ukuran perusahaan semakin tinggi nilai perusahaan. Pengungkapan CSR berpengaruh positif pada nilai perusahaan. Hal ini berarti semakin baik pengungkapan CSR semakin baik nilai perusahaan. GCG sebagai variabel moderasi mampu memperkuat hubungan ukuran perusahaan pada nilai perusahaan. Hal ini dapat menunjukkan bahwa semakin tinggi penerapan GCG maka semakin tinggi kegiatan operasionalnya dan ukuran perusahaan semakin besar. Ukuran perusahaan yang besar akan mencerminkan bahwa perusahaan tersebut sedang mengalami perkembangan dan pertumbuhan yang baik sehingga dapat meningkatkan nilai perusahaan. GCG sebagai variabel moderasi mampu memperkuat hubungan pengungkapan CSR pada nilai perusahaan. Hal ini berarti Hal ini dapat menunjukkan bahwa semakin tinggi penerapan GCG maka semakin tinggi kegiatan operasionalnya dan ukuran perusahaan semakin besar. Ukuran perusahaan yang besar akan mencerminkan 
bahwa perusahaan tersebut sedang mengalami perkembangan dan pertumbuhan yang baik sehingga dapat meningkatkan nilai perusahaan.

Berdasarkan hasil penelitian dan simpulan di atas adapun saran yang dapat diberikan adalah penelitian selanjutnya hendaknya menambah jumlah sampel penelitian karena sampel dalam penelitian ini sangat terbatas, mengingkat jumlah sampel penelitian ini berpatokan pada konsistensi perusahaan dalam mengikuti program CGPI selama periode 2011-2015. Penelitian selanjutnya dapat menggunakan seluruh perusahaan yang mengikuti program CGPI dalam periode 1 tahun untuk mendapatkan jumlah sampel yang cukup dan representatif. Perusahaan hendaknya lebih meningkatkan pengungkapan CSR agar nilai perusahaan semakin meningkat pula dan mempertahankan penerapan GCG mengingat rata-rata perusahaan sampel telah terkategori sangat terpercaya menurut pemeringkatan dari CGPI sehingga pentingnya pengungkapan CSR untuk lebih meningkatkan nilai perusahaan.

\section{REFERENSI}

Ekonomi dan Bisnis Universitas Udayana. Analisa, Yangs. 2011. Pengaruh Ukuran Perusahaan, Leverage, Profitabilitas dan Kebijakan Dividen terhadap Nilai Perusahaan. Skripsi. Universitas Diponogoro.

Astiyani, M Norisa dan I.B. Putra Astika. 2014. Kemampuan Corporate Governance Memoderasi Pengaruh Pengungkapan CSR pada Nilai Perusahaan. E-Jurnal Akuntansi Universitas Udayana, 7(1): h:235-249.

Branco, Manuel C., dan Rodrigues, Lucia L. 2006. Communication of Corporate Social Responsibility by Portuguese Bank: A Legitimacy Theory Perspective. Corporate Communication: International Journal, 11(3): pp:232-248. 
Diah Surya Nita Dwi Lestari dan Ni Gusti Putu Wirawati. Pengaruh...

Bringham, Eugene F dan Houston, Joel F. 2013. Dasar-Dasar Manajemen Keuangan. Edisi 11 Buku 2. Jakarta:Salemba Empat.

Cheng, Ming Chang dan Tzeng Zuwei Ching. 2011. The Effect of Leverage on Firm Value and How the Firm Financial Quality Influence on This Effect. World Journal of Management. 3(2): 30-53.

Deegan, C. 2004. Financial Accounting Theory. McGraw Hill - Book Company, Sidney.

Dewi, Ayu Sri Mahatma dan Ary Wirajaya. 2013. Pengaruh Struktur Modal, Profitabilitas dan Ukuran Perusahaan pada Nilai Perusahaan. E-Jurnal Akuntansi Universitas Udayana, 4(2): h:358-372.

Ferreira et al., 2014. Does it pay to outclass? Corporate Social Responsibility and Its Impact on Firm Value. Financial Management Association Conference. Research Collection Lee Kong Chian School Of Business.

Ghozali, Imam. 2016. Aplikasi Analisis Multivariative dengan Program IBM SPSS 21. Semarang:Badan Penerbit Universitas Diponegoro.

Harjito, D. Agus dan Katiya Nahda. 2011. Pengaruh Corporate Social Responsibility terhadap Nilai Perusahaan dengan Corporate Governance sebagai Variabel Moderasi. Jurnal Siasat Bisnis, 15(1): h:1-12

Indriantoro, Nur dan Bambang Supomo. 2013. Metodologi Penelitian Bisnis untuk Akuntansi dan Manajemen. Yogyakarta:BPFE-Yogyakarta.

Indriantoro, Nur dan Bambang Supomo. 2016. Metodologi Penelitian Bisnis untuk Akuntansi dan Manajemen. Yogyakarta:BPFE-Yogyakarta.

Kaur, Bhupinder. 2015. Impact of Corporate Social Responsibility on the Performance of the Companies. Journal for Studies in Management and Planning, 1(2), March 2015.

Kraft, et al. 2013. Corporate Governance, Value and Performance of firms: New Empirical Results on Convergence from Large International Database. Diakses dari https://halshs.archives-ouvertes.fr/halshs-00786763. Diunduh tanggal 10 Oktober 2017. 
Mc.Donald, L.M., and Rundle-Thiele, S.R. 2008. Corporate Social Responsibility and Bank Customer Satisfaction: A Research Agenda. International Journal of Bank Marketing, 26 (3): pp: 170-182

Medyawati, Henny dan M. Yunanto. 2014. The Influence of Corporate Social Responsibility to the Value of the Company in Indonesia. Conference Paper. Diakses dari https://www.researchgate.net/publication/309486387. Diunduh tanggal 18 September 2017.

Mulia, S. 2010. Pengaruh Corporate Governance terhadap Nilai Perusahaan di BEI Jakarta. Journal of Indonesian Applied Economics, 4 (1).

Mutmainah. 2015. Analisis Good Corporate Governance Terhadap Nilai Perusahaan. Jurnal, diakses dari http://ejournal.stiedewantara.ac.id. Diunduh tanggal 9 September 2017.

Puspita, N.S. 2011. Analisis Pengaruh Struktur Modal, Pertumbuhan Perusahaan, Ukuran Perusahaan dan Profitabilitas terhadap Nilai Perusahaan pada Perusahaan Manufaktur yang terdaftar di Bursa Efek Indonesia periode 2007-2009. Skripsi. Universitas Diponegoro. Semarang.

Putra, Adrie. 2014. The Impact of Implementation Good Corporate Governance to Firm Value (Evidence from Indonesia Public Banking Sector ). Society of Interdisciplinary Business Research. 4(1): h:95-102.

Putri, Ayu Kemala, dkk. 2016. Pengaruh Corporate Social Responsibility terhadap Nilai Perusahaan dengan Ukuran Perusahaan dan Jumlah Dewan Komisaris sebagai Variabel Pemoderasi (Studi pada Perusahaan Manufaktur yang terdaftar Bursa Efek Indonesia). Jurnal Aplikasi Manajemen, 14(2): h:344-358.

Putri, W.H. Rahajeng. 2014. Pengaruh Corporate Social Responsibility terhadap Nilai Perusahaan dan Good Corporate Governance sebagai Pemoderasi pada Industri Makanandan Minuman yang Terdaftar di Bursa Efek Indonesia periode 2010-2013. Diakses dari http://eprints.perbanas.ac.id/1872/1/ARTIKEL\%20ILMIAH.pdf. Diunduh tanggal 9 September 2017.

Prastuti, N.K. Karlina dan I G.A.N. Budiasih. 2015. Pengaruh Good Corporate Governance pada Nilai Perusahaan dengan Moderasi Corporate Social Responsibility. E-Jurnal Akuntansi Universitas Udayana, 13(1): h:114-129. 
Pratama, I G.B. Angga dan I G.B. Wiksuana. 2016. Pengaruh Ukuran Perusahaan dan Leverage terhadap Nilai Perusahaan dengan profitabilitas sebagai Variabel Mediasi. E-Jurnal Manajemen Universitas Udayana, 5(2): h:1338-1367.

Ratnadewi, Putu Ari dan I G.K. Ulupui. 2016. Mekanisme Corporate Governance sebagai Variabel Pemoderasi Pengaruh Pengungkapan Corporate Social Responsibility pada Nilai Perusahaan. E-Jurnal Akuntansi Universitas Udayana, 14(1): h:548-574.

Ratna Kusumayanti, Ni Ketut dan I.B. Putra Astika. 2016. Corporate Social Responsibility Sebagai Pemediasi Pengaruh Ukuran Perusahaan, Profitabilitas dan Leverage pada Nilai Perusahaan. E-Jurnal Akuntansi Universitas Udayana, 15(1): h:549-583.

Retno M, R. Dyah dan Denies Priantinah. 2012. Pengaruh Good Corporate Governance dan Pengungkapan Corporate Social Responsibility terhadap Nilai Perusahaan (Studi Empiris pada Perusahaan yang Terdaftar di Bursa Efek Indonesia Periode 2007-2010). Jurnal Nominal, 1(1): h:84-103.

Rustiarini, Ni Wayan. 2010. Pengaruh Corporate Governance pada Hubungan Corporate Social Responsibility dan Nilai Perusahaan. Simposium Nasional Akuntansi XIII Purwokerto.

Salvatore, Dominick. 2005. Ekonomi Manajerial dalam Perekonomian Global. Jakarta:Salemba Empat.

Setiawan, I Made Agus. 2014. Pengaruh Corporate Social Responsibility, Auditor Opinion, Financial Distress dan Accounting Firm Size terhadap Auditor Switching pada Perusahaan Real Estate and Property yang terdaftar di Bursa Efek Indonesia. Skripsi. Fakultas Ekonomi dan Bisnis Universitas Udayana.

Setiawati, Lulu dan Olivia Tija. 2012. Effect of CSR Disclosure to Value of the Firm: Study for Banking Industry in Indonesia. World Journal of Social Sciences. 2(6): h:169-178.

Servaes, Henri and Ane Tamayo. 2012. The Effect of Corporate Social Responsibility on Firm Value: The Role of Customer Awareness. Forthcoming Management Science. London Business School. 
Siagan, Ferdinand, Sylvia V Siregar and Yan Rahadian. 2013. Corporate Governance, Reporting Quality, and Firm Value: Evidence from Indonesia. Journal of Accounting in Emerging Economies. 3(1): h:4-20.

Sugiono, Lisa Puspitasari dan Christiawan Y. Jogi. Analisa Faktor yang Mempengaruhi Likuiditas pada Industri Ritel yang Terdaftar pada Bursa Efek Indonesia Tahun 2007-2012. Business Accounting Review, 1(2).

Sugiyono. 2014. Metode Penelitian Kuantitatif, Kualitatif dan R\&D. Bandung: Alfabeta

Suwisnaya, I Pande Putu. 2017. Pengaruh Kebijakan Utang pada Nilai Perusahaan dengan Ukuran Perusahaan sebagai Variabel Moderasi. Skripsi. Fakultas

Tjager, I Nyoman et al. 2003. Corporate Governance: Tantangan dan Kesempatan Bisnis bagi Komunitas Bisnis Indonesia. Jakarta: PT Prenhallindo.

Umbara, D.M. Bagus dan I Ketut Suryanawa. 2014. Pengaruh Pengungkapan Tanggung Jawab Sosial pada Nilai Perusahaan. E-Jurnal Akuntansi Universitas Udayana, 9(2): h:410-424.

Undang-Undang Republik Indonesia Nomor 25 Tahun 2007 tentang Penanaman Modal. Diakses dari peraturan.go.id/uu/nomor-25-tahun-2007.html. Diakses pada 10 September 2017.

Undang-Undang Republik Indonesia Nomor 40 Tahun 2007 tentang Perseroan Terbatas. Diakses dari peraturan.go.id/uu/nomor-40-tahun-2007.html. Diakses pada 10 September 2017.

Wiagustini, Ni Luh Putu. 2010. Dasar-dasar Manajemen Keuangan. Denpasar: Udayana University Press. 